\title{
RYTMUS A UDÁLOST KRÁSY
}

\author{
VLASTIMIL ZUSKA \\ Katedra estetiky, Filozofická fakulta, Univerzita Karlova \\ E-mail: vlastimil.zuska@ff.cuni.cz
}

\begin{abstract}
Rhythm and the Event of Beauty

This article starts with an exposition of Whitehead's conception of beauty in his Adventures of Ideas as a quality exemplified in an actual event. On the basis of his distinction between lower and higher forms of beauty we may reasonably infer that beauty, more precisely an experience of beauty, is formed by several nexuses of events, and eventually by a society of events in the special meaning of 'society' in Whitehead's metaphysics - that is, a multiple interconnection of structured contrasts. Comparison of the phases of the constitution of an actual entity, the rhythm in the process of education, and the role of reason in human cognition and behaviour results in the notion of rhythmical interconnection between the 'horizontal' and the 'vertical' dimensions of the aesthetic experience, in which the vertical means the realized relationship between the affective and the 'intellectual' strata of human consciousness, so that the rhythmical interconnection or rhythm of rhythms forms an inherent component of every aesthetic experience, including an event of beauty. Keywords: A. N. Whitehead; rhythm; beauty; contrast; harmonization
\end{abstract}

O kráse, živé estetické hodnotě i estetickém prožitku mluví Whitehead na mnoha místech děl svého metafyzického období, podrobně a systematicky se jim pak věnuje v samostatné kapitole Dobrodružství idejí (Adventures of Ideas, 1933). Vyjdeme proto z tohoto jeho vymezení krásy, abychom následně vzali v úvahu i zmínky dřívější a pozdější a uvedli do souvislostí, mnohdy implicitních, pojetí estetického prožitku (krásy) s rytmem jako jeho neoddělitelnou, dokonce konstitutivní součástí.

„Krása je vzájemná adaptace mnoha faktorů v události zkušenosti. Ve svém primárním smyslu je tedy krása kvalitou, která svou exemplifikaci nachází v aktuálních událostech. " ${ }^{1} \mathrm{~V}$ tomto výměru je krásu pojata jako kvalita, což mimo jiné úzce koresponduje s pojetím krásy jako terciární kvality v díle Whiteheadova staršího souputníka Samuela Alexandera, které vyšlo ve stejný rok jako Dobrodružství idejí. ${ }^{2}$ Událost zkušenosti a vzájemná adaptace ovšem implikuje časovou rozlohu, tedy proces takové, $v$ tomto př́padě úspěšné adaptace relevantních faktorů (relevance opět implikuje selektivitu celého procesu adaptace včetně potlačení či odmítnutí „nevhodných“ faktorů, jak ostatně Whitehead dále upřesňuje). Zaměříme se proto na vnitřní konstituci krásy jako kvality aktuální události, která se ovšem dále značně komplikuje: „Adaptace‘ ale implikuje cíl, završení.

A. N. Whitehead, Adventures of Ideas, The Free Press, New York 1967, s. 252.

2 Srov. S. Alexander, Beauty and Other Forms of Value, Macmillan, London 1933. 
Krásu lze tedy určit jen tehdy, lze-li analyzovat cíl ,adaptace.“3 Cíl adaptace opět naznačuje proces estetického prožitku, dokonce s dalším, v jiných, ontologických souvislostech užívaným pojmem „vábeni““ (lure). Také ohraničení tohoto procesu, které upomene na ohraničenost jako nutnou podmínku každé strukturace (Mukařovský) či každého textu (Lotman), případně vznikajícího celku jako organizujícího principu (Kermode, Smuts), přidává další faktor do komplexního pojetí krásy jako (terciární) kvality události zkušenosti. Whitehead dále upřesňuje dvojí cíl adaptace:

V prvé řadě je to nepř́ítomnost vzájemného rušení různých prehenzí, taková, že intenzity subjektivní formy, která přirozeně a správně, či jedním slovem souladně, vyvstává z objektivních obsahů různých prehenzí, se vzájemně neruší. Když je tohoto cíle dosaženo, máme nižší formu krásy, neprrítomnost bolestného střetu, absenci vulgárnosti. ${ }^{4}$

Opět najdeme dobovou paralelu, tentokrát poněkud starší, a to u Bernarda Bosanqueta v jeho dvojici „snadné a obtížné krásy“ (easy and difficult beauty). ${ }^{5}$ Paralely však nalézáme také v mnohem současnějších přístupech, zejména v oblasti dnešních kognitivních (neuro)věd, př́ípadně kognitivní psychologie. První cíl souladu subjektivní formy, různých prehenzí a objektivních obsahů, koresponduje s konceptem percepční plynulosti, kterou zkoumá i současná neuroestetika, a s rozšířeným konceptem plynulosti zpracování (nejen) percepční informace. ${ }^{6}$ Primární soulad intenzit subjektivní formy je ale jen první úrovní estetického prožitku, v souladu s členěním současných kognitivních věd můžeme říci úrovní afektivní. Whitehead postupuje dále:

$\mathrm{V}$ druhé řadě existuje vysoká forma krásy. Tato forma předpokládá první formu a připojuje k ní podmínku, že konjunkce v jedné syntéze různých prehenzí zavádí nové kontrasty objektivních obsahů. Tyto kontrasty zavádějí nové, slad’ované intenzity pocitování, přirozené pro každý z nich, a tím vyvolávají intenzity sladěného pocitování v primitivních, primárních složkách pocitování. ${ }^{7}$

Povšimněme si důrazu na „nové kontrasty“, protože pojem kontrastu hraje u Whiteheada roli nejen $\mathrm{v}$ dřívějším traktování krásy (jako kontrastu v rámci jednoty), ale též jako báze jakýchkoli vztahů v Procesu a realitě, přičemž rytmus můžeme nepochybně chápat také jako typ vztahu. V dílčím shrnutí Whitehead uvádí: „Tedy části přispívají $\mathrm{k}$ masivnímu pocitování celku a celek přispívá $\mathrm{k}$ intenzitě pocitování částí. Takto jsou subjektivní formy těchto prehenzí mnohonásobně a propojeně uspořádány ve strukturovaných kontrastech." ${ }^{8}$ Pocitování celku, tedy vliv celku jako organizujícího principu (ve smyslu holismu J. Smutse) ovšem, má-li působit od počátku estetického prožitku krásy, musí vznikat a vyvíjet se, musí rovněž obsahovat anticipační fázi, kterou u Whiteheada, v pojetí události, také obsahuje. Jak se pokusíme ukázat, vznikající komplexní celek

\footnotetext{
A. N. Whitehead, Adventures of Ideas, viz výše, s. 252.

Tamtéž.

B. Bosanquet, Three Lectures on Aesthetic, Macmillan, London 1915.

Srov. R. Reber; N. Schwarz; P. Wilkielman, Processing Fluency and Aesthetic Pleasure: Is Beauty in the Percipient's Processing Fluency?, Personality and Social Psychology Review, roč. 8, 2004, č. 4, s. 364-382. A. N. Whitehead, Adventures of Ideas, viz výše, s. 252.

Tamtéž.
} 
strukturovaných kontrastů pak nutně a konstitutivně obsahuje rovněž komplexní rytmus, řečeno s „raným“ Whiteheadem, rytmus rytmů. ${ }^{9}$ Whitehead de facto postuluje "dvourychlostní “ procesy/akty vědomí při estetické recepci, mimo jiné proto, že rytmus rytmů u vysoké formy krásy vyžaduje vyšší úrovně pocitování (slovy A. Damasia pocitování pocitů), reflektované, volní zpracování informace, tvorby rozhodnutí a soudů, mentální úsilí na rozdíl od plynulého, automatizovaného, intuitivního či afektivního prožitku „snadné krásy“. Tato stratifikace je námětem soudobých kognitivních věd včetně neuroestetiky, kde se začaly brát v úvahu jak „primární adaptace prehenzí, tak i vyšší, tj. komplexnější úrovně estetických objektů/uměleckých děl, zjednodušeně řečeno, nejen „pouhé“ jevení se, ale i významy konstituované na základě primárních vjemů. ${ }^{10}$ Otázkou zůstává přechod a propojení mezi nižší a vyšší formou krásy, stejně tak jako přechod, resp. integrace afektivní roviny pocitování, prožívání, osmyslení s úrovní „pomalého“ myšlení. Pokusíme se proto $\mathrm{v}$ řadě Whiteheadových prací vysledovat jednu $\mathrm{z}$ možných odpovědí, kterou je, jak se zdá, právě rytmus, resp. rytmus rytmů. Z událostní povahy estetického prožitku také vyplývá nejen „horizontální“ integrace jednotlivých prehenzí a primárních subjektivních forem, tzn. integrace v čase, ale i „vertikální“ integrace různých úrovní včetně výše uvedené afektivní a význam intendující vyšší úrovně zpracování informace. V tomto smyslu Whitehead v analýze prožitku krásy pokračuje a zde můžeme nalézt implikaci rytmu jako konstitutivního faktoru:

Existuje jisté rozdělení různých prehenzí z toho důvodu, že každá část úplného objektivního data vnucuje svou slad’ující kvalitativní reprodukci do subjektivní formy. Do té míry, do níž se identické kvality vyskytují v různých objektivních datech, musí pak být účinnost této kvality v subjektivní formě diktována procesem integrace a také kompatibilitou s ostatními kvalitativními pocitováními. Rozložení subjektivní formy mezi jednotlivé, oddělené prehenze tedy odkazuje primárně ke sladujícím zdrojům subjektivní formy, odvozeným od různých složek úplného objektivního data. ${ }^{11}$

Plné porozumění uvedenému citátu i částem předchozím by vyžadovalo obšírný výklad pojmů prehenze, ${ }^{12}$ subjektivní forma, objektivní datum a kvalitativní pocitování. Zde se spokojíme s nutným odkazem na událostní charakter prožitku krásy/estetického prožitku, potřebným pro následnou argumentaci, a tedy stručné vymezení složitého a proměnlivého pojmu událost. Od počátku jakéhokoli výkladu Whiteheadova pojmu událost narážíme na částečnou synonymitu a hierarchizaci. Až v Procesu a realitě rozlišuje occasion a event, což sice obojí můžeme přeložit jako „událost“, ale event je ve skutečnosti (v Procesu a rea-

9 V souvislosti se dvěma úrovněmi Krásy zavádí Whitehead právě koncept rytmu rytmů: „Existuje stupňování rytmu. Dokonalejší rytmus je založen na složkových, dílčích rytmech. [...] Každý velký rytmus tedy předpokládá nižší rytmy, bez nichž by nemohl vzniknout.“ A. N. Whitehead, An Enquiry Concerning the Principles of Natural Knowledge, Cambridge University Press, Cambridge 1955, s. 198.

10 Srov. B. Belke; H. Lecler; T. Strobach, Cognitive Fluency: High-Level Processing Dynamics in Art Appreciation, Psychology of Aesthetics, Creativity, and the Arts, roč. 4, 2010, č. 4, s. 214-222. Obecnější pojetí dvou úrovní zpracování informace podává Daniel Kahneman. Srov. D. Kahneman, Thinking Fast and Slow, Penguin, London 2011.

11 A. N. Whitehead, Adventures of Ideas, viz výše, s. 255.

12 Pro lepší porozumění dosavadní argumentaci a citacím alespoň stručné vymezení: prehenze je operací, kterou aktuální entita (událost, udání se) ve své sebetvorbě, ve svém nastávání, uchopuje jiné entity a činí z nich objekt (objektivní datum) své sebeutvářející zkušenosti. 
litě) nexem elementárních „aktuálních událostí“ (actual occasions), které jsou synonymní s aktuální entitou jako nejzákladnějším „stavebním kamenem“ univerza. Jak ještě ukážeme, události se mohou řetězit, vytvářet nexy a ty dále „společenstvi“ (society). Poněkud předběhneme a předznamenáme, že estetický prožitek a jeden z jeho typů, titulní „událost krásy“, je právě společenstvím. Whitehead se pochopitelně vymezováním a definováním aktuální události, nejreálnějším prvkem jeho univerza, zabývá na mnoha místech. Pro naše účely volíme nejpropracovanější systematické pojetí z Procesu a reality:

Aktuální událost není ničím jiným nežli jednotou náležející specifickému př́ípadu konkrescence. Konkrescence tedy není nic jiného než reálná vnitřní konstituce př́islušné aktuální události. Analýza formální konstituce aktuální entity [tedy události - pozn. V. Z.] skýtá tři stadia procesu pocitování - responzní fázi, doplňující stadium a uspokojení. Uspokojení je toliko kulminací, označující nejprve rozptýlení veškeré neurčitosti [...] uspokojená, naplněná aktuální entita ztělesňuje jednoznačný postoj ,ano nebo ,ne. Proces sám vychází ze dvou předchozích fází. První fáze je fází čiré recepce aktuálního světa v jeho podobě objektivního data pro estetickou syntézu. Druhá fáze je řízena soukromým ideálem, postupně tvarovaným v procesu samém, čímž se mnohost pocitování, odvozeně cítěných jako cizí, transformuje do jednoty estetického uvědomění a zhodnocení, bezprostředně pocitovaného jako soukromé. Toto je vstup žádostivosti, kterou v případě komplexnějších procesů nazýváme vizí. ${ }^{13}$

Jednoznačný hodnotící postoj, elementárnost aktuální entity, a jak ukážeme, jedna ze subfází druhé fáze konstituce ukazují na současný model afektivní heuristiky a pole zkoumání neuroestetiky, která se ve většině případů omezuje pouze na afektivní úroveň zpracování informace (efekt vystavení, percepční plynulost). Dříve než uvedeme komplexnější pojetí seskupování aktuálních entit a vnitřní členění druhé fáze konstituce aktuální entity, které zavádí již připomenutou vertikální dimenzi aktuální události, zmíníme paralely mezi konstitucí nejzákladnější jednotky univerza - aktuální entity/události - a obdobnými, ale mnohem komplexnějšími procesy typu vzdělání a funkce rozumu, které spojuje jak podobnost konstitutivních fází, tak „pojítko“ vertikální i horizontální dimenze procesu estetického prožitku - rytmus. Heuristická smysluplnost takového paralelismu vychází z Whiteheadovy teze, že „[k]aždá aktuální entita je sama o sobě popsatelná pouze jako organický proces. Opakuje v mikrokosmu to, čím je univerzum v makrokosmu. Je to proces postupující od fáze $\mathrm{k}$ fázi, každá fáze je pak reálným základem, z níž její následník postupuje k završení příslušné entity. "14 A zde můžeme dodat jistě zkratkovitou, ale v rámci Whiteheadova systému doložitelnou tezi, že kde jsou fáze, tam je rytmus.

V souboru studií Cíle vzdělávání (The Aims of Education, 1932) jsou zahrnuty kapitoly s názvem „Rytmus vzděláni“" (The Rhythm of Education) a následně „Rytmické nároky svobody a disciplíny“ (The Rhythmic Claims of Freedom and Discipline): „Vnitřní duchovní život člověka je sít’ s mnoha vlákny. Ta se nevyvíjí jednotně. [...] Rozvoj mentality vykazuje sám o sobě rytmus zahrnující propojení cyklů, celý proces je pak ovládán větším cyklem téhož obecného charakteru jako jeho malé víry. “15

13 A. N. Whitehead, Process and Reality, The Free Press, New York 1978, s. 212.

14 A. N. Whitehead, Process and Reality, viz výše, s. 215.

15 A. N. Whitehead, The Aims of Education, Williams nad Norgate, London 1932, s. 43. 
Připomeňme, že Whitehead shledává $\mathrm{v}$ optimálním procesu vzdělávání tři stadia či fáze (srovnejme s fázemi stávání aktuální entity): stadium romance, precizace a generalizace. Rytmus, zahrnující propojení cyklů, včetně zastřešujícího, většího cyklu, je evidentně rovněž rytmem rytmů, o němž Whitehead mluví již ve své rané práci $\mathrm{z}$ „naturfilosofického" období. Srovnejme menší cyklus - fázi Romance ve vzdělání - s výše uvedenou první fází konstituce aktuální entity - čirou recepcí aktuálního světa:

Prozkoumejme nyní blíže rytmus přirozeného úsilí inteligence. Prvním postupem mysli v novém prostředí je poněkud diskurzivní aktivita mysli, zatížená ideami a zkušeností. Je to proces objevování, proces postupného zvykání si na překvapivé myšlenky, proces formulování otázek, hledání odpovědí, produkování nových zážitků, všímání si toho, co se děje jako výsledek nových dobrodružství. ${ }^{16}$

Obdobně bychom mohli porovnávat další fáze stávání se aktuální události/entity a postup vzdělání a našli bychom řadu podobností, s odpovídajícím vzorcem cyklů v cyklech, vnitřních fází ve fázích komplexnějších a nižších rytmů rytmizovaných v hierarchicky vyšších rytmech rytmů. Whitehead v uvedeném citátu i jinde vlastně popisuje kognitivní operace konceptualizace (zátěž idejemi a zkušenostmi) včetně sebereflexe (všímání si výsledků...). Proto také dospívá $\mathrm{k}$ dílčímu závěru, že „nemůžete bez ztráty ignorovat $\mathrm{v}$ duševním životě tak zásadní faktor, jakým je umění. Naše estetické emoce nám zajištují živé porozumění a oceňování hodnot“.17 Jak ukážeme dále, „živé“ porozumění rytmus nejen implikuje, ale dokonce ho nutně vyžaduje. Mimo jiné z časové perspektivy, která se objevuje jako inherentní faktor aktuální události již čtyři roky před knihou Proces a realita:

Událost má současníky. To znamená, že událost v sobě zrcadlí mody svých současníků jako bezprostředního dosažení/dokončení. Událost má minulost. To znamená, že událost v sobě zrcadlí mody svých předchůdců jako vzpomínky, které se propojují do jejího vlastního obsahu. Událost má budoucnost. To znamená, že událost v sobě zrcadlí takové aspekty, které budoucnost vrhá zpět na př́tomnost, nebo jinými slovy, jak byla přítomnost určena, pokud jde o budoucnost. Událost tedy má anticipaci. ${ }^{18}$

V uvedeném citátu můžeme vystopovat jak horizontální propojení ve smyslu minulost - prrítomnost - budoucnost, tak i vertikální, ve smyslu simultánního vrstvení konstituce. Propojování, zrcadlení, anticipace rovněž implikují rytmus jako integrální součást, $\mathrm{v}$ př́padě prehenze objektivních dat, tj. modů předchůdců aktuální entity ve smyslu formy prehenze, která se zároveň prodlužuje do budoucnosti a je coby anticipace ovlivněna rytmem jako jedním ze zásadních anticipačních vodítek, podobně jako zastřešující cyklus předjímá uzavření díličích cyklů.

V prípadě vzdělání mluví Whitehead o třech stadiích rytmické jednoty vývoje. „Obecně řečeno, celé období vzdělání je ovládáno tímto trojitým rytmem. "19 Tento trojitý rytmus, tedy tři různé rytmy (cykly), je zastř̌ešen jednotícím rytmem, obecnějším cyklem,

\footnotetext{
16 Tamtéž, s. 50.

17 Tamtéž, s. 63.

18 A. N. Whitehead, Science and the Modern World, Pelican Mentor Books, New York 1948, s. 74.

19 A. N. Whitehead, The Aims of Education, viz výše, s. 59.
} 
a tuto rytmickou figuru můžeme přenést na nižší i vyšší roviny rytmů včetně rytmu estetického prožitku. Vertikální rozměr rytmizace můžeme dále vysledovat v rozlišení uvnitř druhé fáze nastávání aktuální entity:

Druhá fáze, fáze doplňování, se sama dělí na dvě podřízené fáze. Obě tyto fáze mohou být jednoduché, triviální, také nejsou zcela oddělitelné, protože spolu interferují bud' intenzifikací, nebo inhibicí. [...] Z těchto dvou subfází ta první - v míře, v níž zde existuje řád - je subfází estetického doplnění a druhá intelektuálního doplnění. ${ }^{20}$

První subfází v případě aplikace na komplexní estetický prožitek je fáze percepční, a to na úrovni afektivity, tedy bezprostřední emocionální reakce, hodnocení a intuitivních soudů, jak potvrzují současní neurofilosofové. Whitehead sám dodává:

V estetickém doplnění dochází k emocionálnímu hodnocení a chápání kontrastů a rytmů, inherentních ve sjednocování objektivního obsahu v konkrescenci jedné aktuální události. $\mathrm{V}$ této fázi je percepce zesílena přijímáním bolesti a libosti, krásy a odporu. Je to fáze inhibicí a intenzifikací. ${ }^{21}$

Uchopování kontrastů a rytmů samo implikuje, včetně naznačeného střídání inhibicí a intenzifikací, vyšší rytmus/rytmy. Dvě subfáze druhé fáze konkrescence aktuální události upomenou na již naznačené dva typy myšlení, vnímání, hodnocení, na něž jsme krátce upozornili výše. Zmíněný Daniel Kahneman ve svém bestselleru postuluje dva systémy myšlení (S1 a S2, S zastupuje „systém“). Systém 1, rychlé myšlení, zahrnuje tzv. afektovou heuristiku, „kde soudy a rozhodování jsou řízeny přímo pocity líbení nebo nelíbení, s minimálním podílem záměrnosti a uvažování“22 Záměrné, racionální, diskurzivní, logické či konceptuální myšlení je pak v porovnání s afektovou heuristikou „pomalë“. Paralelu mezi Whiteheadovými subfázemi druhé fáze konkrescence aktuální entity a systémy 1 a 2 můžeme s ohledem na rytmus uzavřít velkým návratným obloukem k Platonovi, který tvrdí: „Tak také i rytmus vznikl z rychlého a pomalého, jež se dříve různily, později se však uvedly v soulad. “23 Ukazuje se tedy, že sjednocující, harmonizující, syntetizující role rytmu se realizuje $\mathrm{v}$ několika úrovních a $\mathrm{v}$ několika dimenzích, které jsme zjednodušeně převedli na vertikální (sladění estetického a intelektuálního doplňování) a horizontální, fungující $\mathrm{v}$ procesu estetického prožitku, který $\mathrm{v}$ našem, tj. makroskopickém světě nemưžeme redukovat na jedinou událost, a dokonce ani na „pouhý“ nexus událostí, protože tím bychom ztratili zmíněný vertikální rozměr tohoto procesu, který evidentně existuje (připomeňme třeba kumulaci významů v kontextu jako typu celku v umění u Mukařovského). ${ }^{24}$ Roli intelektu, resp. rozumu, který se rovněž projevuje rytmicky, ostatně Whitehead zkoumá v samostatné monografii, kde v souladu se svou koncepcí rytmu vzdělávání uvádí:

Když ale mentalita pracuje na vysoké úrovni, vnáší novost do žádostivosti mentální zkušenosti. V této funkci je obsažen prvek čiré anarchie. Ale mentalita se zároveň stává

\footnotetext{
A. N. Whitehead, Process and Reality, viz výše, s. 213.

Tamtéž.

D. Kahneman, Thinking Fast and Slow, viz výše, s. 12.

Srov. Platón, Symposion, OIKOYMENH, Praha 1993.

24 Srov. J. Mukařovský, Pojem celku v teorii umění, in: J. Mukařovský, Cestami poetiky a estetiky, Československý spisovatel, Praha 1971, s. 85-98.
} 
samoregulující. Usměrňuje své vlastní operace svými vlastními soudy. Zavádí vyšší žádostivost, která rozlišuje mezi vlastními anarchistickými výtvory. Objevuje se Rozum [...]. Musíme uvážit vstup anarchie, revoltu proti anarchii, užití anarchie a regulaci anarchie. Rozum civilizuje hrubou sílu anarchistické žádostivosti. Bez anarchistického puzení je prŕroda odsouzena k pomalému úpadku do nicoty. Pouhá opakující se zkušenost postupně eliminuje prvek po prvku a vede do prázdna. ${ }^{25}$

V tomto popisu úlohy Rozumu ve vědomí můžeme zaznamenat jak rytmus vzdělání uvedený výše, tak implicitní kreativní postup př́rody (vstup anarchie), který je pro Whiteheada rovněž rytmizovaný, stejně jako pohyb přírody i lidského vědomí mezi nicotou a prázdnem nebo - z perspektivy rytmu - mezi chaosem a nehybností krystalu. ${ }^{26} \mathrm{Než}$ přejdeme k explikaci zdánlivě paradoxního pojetí rytmu jako fúze trvajícího, opakování a nového, změny - v našem konkrétním př́ípadě estetického prožitku, resp. události krásy -, musíme upřesnit, jaký typ události tento prožitek představuje. Zjevně nevystačíme se „základním kamenem“ Whiteheadova univerza - aktuální událostí, kterou Whitehead vymezuje následovně:

aktuální udání se je jednotkou komplexního pocitování, ultimátním výtvorem odvozeným z kreativního procesu. Událost je obecnější, je to nexus aktuálních udání se, vzájemně propojených určitým způsobem - bud’ nexus ve své formální úplnosti, nebo v objektivizovaném nexu. Mezním př́padem události je jediné aktuální udání se. ${ }^{27}$

Pro proces estetického prožitku zjevně nevystačíme ani s udáním se, ale ani s aktuální událostí/entitou. Prozkoumat proto musíme Whiteheadovu analýzu seskupování událostí, kde podrobněji rozpracovává možné typy propojování jednotlivých událostí, typy nexů a jejich vícenásobné propojení v konceptu „společenstvi“" (society). V př́ílušné kapitole Dobrodružství idejí („The Grouping of Occasions“) rozlišuje nejprve čistě časový nexus událostí, který je kontinuální tehdy, je-li tvořen „soumeznými“ (contiguous) událostmi, a představuje tedy nepřerušenou linii časového řádu. ${ }^{28}$ Při zahrnutí prostoru do vymezení nexu a rozdílech pouze v čistě extenzivním „Vzorci“ (pattern), ale při abstrahování od kvalitativních faktorů, vpletených do struktury, dostáváme druh strukturovaného nexu. Ani ten neodpovídá procesu estetického prožitku, protože tento proces by bez kvalit či „kvalitativních faktorư “ nemohl nastat. Zbývá tedy nejkomplexnější typ sdružení událostí - „společenství“ (society), nexus, který vykazuje jistý typ „sociálního řádu“, a to tehdy, splňuje-li následující podmínky:

1. vykazuje společný formální prvek, projevující se v určitosti každé z obsažených aktuálních entit, 2. tento společný formální prvek vyvstává v každém z členů tohoto nexu $\mathrm{z}$ důvodu podmínek vložených na něj jeho prehenzemi některých dalších členů nexu

25 A. N. Whitehead, The Function of Reason, Beacon Press, Boston 1958, s. 34.

26 „Esencí rytmu je fúze stejného a nového. Celek tak nikdy neztrácí esenciální jednotu struktury, přičemž části vykazují kontrast, vznikající z novosti jejich detailů. Pouhé opakování zabíjí rytmus stejně jako pouhé zmatení diferencí. Krystal postrádá rytmus kvůli přebytku vzorce, zatímco mlha je nerytmická v tom, že vykazuje nestrukturovanou změt detailů." A. N. Whitehead, An Enquiry Concerning the Principles of Natural Knowledge, viz výše, s. 198.

27 A. N. Whitehead, Process and Reality, viz výše, s. 80.

28 Tamtéž, s. 202. 
a 3. tyto prehenze vkládají tuto podmínku reprodukce z důvodu jejich zahrnutí pozitivních pocitování, vykazujících onu společnou formu. Takový nexus nazývám ,společenstvím a společnou formu ,určující charakteristikou' tohoto společenství. ${ }^{29}$

Za určující charakteristiku estetického prožitku, v němž jsou „subjektivní formy prehenzí mnohonásobně a propojeně uspořádány ve strukturovaných kontrastech“, a jde tedy rozhodně o nexus „společenstvi“, můžeme pokládat specifický rytmus tohoto prožitku jako společný formální prvek jeho prvků či fází, a to, jak jsme již naznačili, v dopředné sukcesivitě stejně jako ve vertikalitě vrstvených, překrývajících se vrstev vědomí v aktualitě prožitku.

Whitehead už v úvodním díle svého metafyzického období vymezuje temporalizaci jako „sukcesivní realizaci epochových trvání“.30 Tento názor, který pokračuje i v následných textech, lze spolu s Whiteheadovým současníkem a kolegou Johnem Deweym shrnout např́ílad formulací, že „[k]aždá vědomá zkušenost je zcela jednotný pulz v kontinuálním proudu“. ${ }^{31}$ Těsnou paralelu s touto periodicitou, pulzováním žité zkušenosti, najdeme i o dost později u francouzského psychologa Paula Fraisse, který ji vyjadřuje metaforou: „jako by se prritékající proud nabíral do hrsti a periodicky zase vyléval.“32

V podkapitole „Stadia mentálního růstu“ (Stages of Mental Growth) v citovaném díle Cíle vzdělávání aplikuje Whitehead své pojetí temporality i na vzdělání a život sám, když ř́ká:

Život je esenciálně periodický. Slučuje denní periody s jejich střídáním práce a her, aktivity a spánku. [...] Existují ale subtilnější periody mentálního růstu, s jejich cyklickými opakovanými výskyty, leč vždy odlišné, když přecházíme od cyklu k cyklu, třebaže podřízená stadia se v každém cyklu reprodukují. Proto jsem zvolil termín ,rytmický, mínící zásadní přenos diference $\mathrm{v}$ rámci opakování. ${ }^{33}$

Naši úvahu zakončíme citátem a prvním vymezením krásy u Whiteheada v (Náboženství ve vývoji, Religion in the Making, 1927): „Veškerá estetická zkušenost je pocitování vznikající z realizace kontrastu v rámci jednoty. “34 Můžeme tedy shrnout, že komplexní estetický prožitek (Krásy) je rytmickou pulzací diferencí, kontrastů a sjednocování, jehož „nosnou vlnou“ je rytmus rytmů, specifický pro každou estetickou zkušenost.

\section{Poděkování}

Text vznikl za podpory grantového projektu GA16-13208S Proces a estetika: explicitní a implikovaná estetika v procesuální filozofii Alfreda North Whiteheada.

9 Tamtéž, s. 203.

A. N. Whitehead, Science and the Modern World, viz výše, s. 138.

31 J. Dewey, Whitehead's Philosophy, in: J. Dewey, Problems of Men, Philosophical Library, New York 1946, s. 412.

32 P. Fraisse, Psychologie du rythme, PUF, Paris 1974, s. 17.

33 A. N. Whitehead, The Aims of Education, viz výše, s. 27.

34 A. N. Whitehead, Religion in the Making, Cambridge University Press, Cambridge 1927, s. 101-102. 


\section{LITERATURA}

Alexander, S., Beauty and Other Forms of Value, Macmillan, London 1933.

Belke, B.; Lecler, H.; Strobach, T., Cognitive Fluency: High-Level Processing Dynamics in Art Appreciation, Psychology of Aesthetics, Creativity, and the Arts, roč. 4, 2010, č. 4, s. 214-222.

Bosanquet, B., Three Lectures on Aesthetic, Macmillan, London 1915.

Dewey, J., Whitehead's Philosophy, in: Dewey, J., Problems of Men, Philosophical Library, New York 1946, s. $410-418$.

Kahneman, D., Thinking Fast and Slow, Penguin, London 2011.

Mukařovský, J., Pojem celku v teorii umění, in: Mukařovský, J., Cestami poetiky a estetiky, Československý spisovatel, Praha 1971, s. 85-98.

Fraisse, P., Psychologie du rythme, PUF, Paris 1974.

Platón, Symposion, OIKOYMENH, Praha 1993.

Reber, R.; Schwarz, N.; Wilkielman, P., Processing Fluency and Aesthetic Pleasure: Is Beauty in the Percipient's Processing Fluency?, Personality and Social Psychology Review, roč. 8, 2004, č. 4, s. 364-382.

Whitehead, A. N., Adventures of Ideas, The Free Press, New York 1967.

---, An Enquiry Concerning the Principles of Natural Knowledge, Cambridge, Cambridge University Press, 1955.

---, Process and Reality, The Free Press, New York 1978.

---, Religion in the Making, Cambridge University Press, Cambridge 1927.

---, Science and the Modern World, Pelican Mentor Books, New York 1948.

---, The Aims of Education, Williams nad Norgate, London 1932.

---, The Function of Reason, Beacon Press, Boston 1958. 